To cite: C Mbazira \& T Namatovu 'Civic space and human rights advocacy in the extractive industry in Uganda: Implications of the 2016 Non-Governmental Organisations Act for oil and gas civil society organisations ' (2018) 18 African Human Rights Law Journal 75-99 http://dx.doi.org/10.17159/1996-2096/2018/v18n1a4

\title{
Civic space and human rights advocacy in the extractive industry in Uganda: Implications of the 2016 Non-Governmental Organisations Act for oil and gas civil society organisations
}

\section{Christopher Mbazira}

Associate Professor and Acting Principal, School of Law, Makerere University; Co-ordinator of the Public Interest Law Clinic, Makerere University, Kampala, Uganda

\section{Teddy Namatovu}

Programme Intern, Better Migration Management, Deutsche Gesellschaft für Internationale Zusammenarbeit (GIZ), GmbH Ethiopia and Djibouti

\section{Summary}

The discovery of oil and gas in Uganda has been identified as having the potential to transform Uganda's economy, moving Uganda away from a predominantly low-income to a competitive upper-middle-income country by 2040. However, this discovery has precipitated human rights violations and abuses, especially in the Albertine Graben, where the oil exploration activities are concentrated. For example, the acquisition of land for oilrelated infrastructure has changed the patterns of use of land and water, and people are already experiencing negative effects, such as a loss of livelihood and resources. Civil society organisations aimed at addressing these human rights issues in the sector face a number of hurdles despite constitutional protection and ratification of international instruments that

* LLB (Makerere) LLM (Pretoria) PhD (Western Cape); chrismbazira@gmail.com. This article was developed from a research report entitled 'Assessing the implications of the Non-Governmental Organisations Act, 2016 on NGOs working on natural resource governance in Uganda', commissioned by Global Rights Alert (GRA). Comments and suggestions made by Winfred Ngabiirwe and James Muhindo on the research report are acknowledged.

** LLB (Makerere) LLM (Pretoria); Tednamatovu@gmail.com 
guarantee fundamental rights for CSO operations in the country. Currently, CSOs are governed by the recently-enacted Non-Governmental Organisations Act of 2016. This Act is accompanied by other laws, such as the Public Order Management Act. These laws have created several stumbling blocks that have frustrated CSO efforts in the fulfilment of their mandate. The weight of these laws is especially felt by NGOs working on sensitive issues such as natural resource governance. The article analyses the impact of the legislative framework governing CSOs, specifically the NGO Act, on organisations addressing or working on oil and gas issues in Uganda. In addition to the NGO Act, other pieces of legislation that have a direct bearing on the activities of these organisations are also analysed.

Key words: freedom of association; civil society; extractive industry; nongovernmental organisations; civic space

\section{Introduction}

Notwithstanding Uganda's constitutional provisions and the ratification of several international human rights instruments providing for freedom of expression and association, civic space in the country has constantly been under threat. Civil society operations in the country are continually affected by the enactment of legislation that either directly or indirectly affects civil society work. Legislations such as the Public Order Management Act (POMA) are used by security agencies to frustrate civic engagement, in some cases by deploying security personnel to disperse gatherings and arrest those involved. This state of affairs may be understood in the context of the global war against terrorism, which has seen many governments use terrorism as a pretext for undermining civil liberties. The Arab Spring uprisings, which saw the fall of governments in Egypt and Tunisia, pushed governments, especially in Africa, into a frenzied restriction on freedom of assembly and expression.

It is in this spirit that the promulgation of the Non-Governmental Organisations Act of 2016 (NGO Act) was received by civil society organisations (CSOs) in Uganda. Many CSOs perceived the law as a ploy by the state to tighten its grip on civil society engagement in the country. From its inception as the NGO Bill, the proposed law received a negative response from CSOs, with a number of them publishing position papers challenging some clauses and the spirit of the law. The objectors urged government to ensure that the

1 See Human Dignity Trust 'Note on the Non-Governmental Organisations Bill', http://www.humandignitytrust.org/note_on_the_NGO_Bill_2015_20150506.pdf (accessed 8 August 2016); Human Rights Network Uganda 'Analysis of the NonGovernmental Organisations Bill, 2015' http://www.hurinet.or.ug/ANALYSIS-OFNGO-BILL.pdf.2015-8-13 (accessed 20 March 2017); Human Rights Awareness and Promotion Forum 'The NGO Bill 2015 and its practical and human rights implications on organisations working on the rights of marginalised persons' May 2015. 
proposed law conformed to internationally-acceptable standards on freedom of expression and association. ${ }^{2}$ CSOs called for the revision of several clauses in the Bill. Nonetheless, although some contentious provisions eventually were removed, the Act as it currently stands continues to present a threat to the operations of CSOs.

In the civil society sector the organisations that have been most affected by state regulation include those working on issues of anticorruption; electoral democracy; governance; and human rights, as well as those working on accountability and social justice issues in the extractive sector. This article is concerned with CSOs working on issues relating to oil and gas. These CSOs have committed their time and resources to promoting access to information for citizens in order to promote citizen participation in shaping and monitoring sector developments. In addition to informing the policy and legal framework for the oil and gas sector, a number of organisations have been involved in advocacy for fair and just acquisition of land for sector activities, environmental protection, as well as advocacy for transparency and accountability in the management of revenues from the oil sector.

The Ugandan government in 2006 announced that large deposits of oil had been discovered in several parts of the country, most of it in the Albertine region in Western Uganda. ${ }^{3}$ Presently, three oil companies, Total, CNOOC and Tullow, have production licences, and control 54,9 per cent, 33,3 per cent and 11,76 per cent respectively of the upstream oil sector. Nonetheless, the oil sector has also been characterised by controversy arising from government secrecy regarding matters in this sector, including the terms of the concessions to oil companies; the exact extent of deposits; the impact on the environment; the role of players in the sector; and revenue so far collected and how these revenues are managed. Other concerns relate to the acquisition of land by both the government and private sector to facilitate oil activities and revenue-sharing with local communities. Indeed, negative experiences of other African countries has encouraged CSOs in Uganda to raise public interest in this sector, albeit causing some discomfort on the part of government. For this reason government has moved fast to regulate the activities of CSOs in this sector, sometimes by imposing ad hoc regulations applicable only to organisations working on oil and gas and in the oil-rich region. The 2016 NGO Act is viewed as part of the range of regulatory laws that could negatively impact on the work of CSOs working on oil and gas.

2 As above.

3 See 'Uganda confirms new oil deposits' $B B C$ News http://www.bbc.com/news/ business-19637784 (accessed 18 January 2017). 


\section{Context of oil and gas and civil society work}

Mineral wealth, including oil and gas (also commonly known as the extractive sector), for some time has been viewed as a vehicle through which countries can attain economic development and overcome poverty. In fact, the extractive sector in Uganda has been identified by government as an important segment of the economy contributing to the transformation of the country. The flagship Vision 2040 has earmarked oil and mineral resources as critical in changing 'the country from a predominantly low income to a competitive upper middle income country within 30 years with a per capita income of USD $9500^{\prime}$. $^{4}$

However, the paradox is that, although there are exceptions such as Botswana, mineral wealth in Africa has not brought much-needed economic development. It has, for instance, been demonstrated that some countries with vast mineral wealth, such as the Democratic Republic of the Congo (DRC), Chad and Sudan-Khartoum, are among countries at the bottom of the United Nations Development Programme (UNDP) Human Development Index. ${ }^{5}$

The paradox, dubbed 'the oil curse', has been associated with a number of factors, the most important of which is bad resource governance. ${ }^{6}$ Among others, bad governance in the sector has been characterised by a lack of transparency at different levels, which the World Bank has described to include (i) the award of contracts and licences; (ii) the regulation and monitoring of operations; (iii) the collection of taxes and royalties; (iv) revenue management and allocation; and ( $v$ ) the implementation of sustainable development policies and projects. ${ }^{7}$ It is as a result of this that since the 1990s much time and resources have been invested in campaigns aimed at promoting transparency in the oil sector and putting in place norms and standards for this purpose. The justification for taking this direction came after a number of civil society expositions and the publication of corruption and abuse in the extractive sector. ${ }^{8}$ These campaigns were successful to the extent that international financial institutions such as the World Bank included conditions relating to

4 See Government of Uganda, Vision 2040 'A transformed Ugandan society from a peasant to a modern and prosperous country within 30 years', http://gov.ug/ content/uganda-vision-2040 (accessed 21 March 2017).

5 J van Alstine et al 'Resource governance dynamics: The challenges of "new oil" in Uganda' (2014) 40 Resources Policy 48.

$6 \quad$ Van Alstine et al (n 5 above) 49.

7 See EM Alba 'Extractive industries value chain' Extractive Industries for Development Series 3, Africa Region Working Paper Series 125, The World Bank Washington, as referenced by Van Alstine et al (n 5 above) 50.

8 See A Gillies 'Reputational concerns and the emergence of oil sector transparency as an international norm' (2010) 54 International Studies Quarterly 103. 
transparency as prerequisites for funding some extractive-related projects. $^{9}$

In addition to the governance deficits, but also as a result of these, activities in the extractive industry have given rise to a number of human rights issues. There have been issues around economic, social and cultural rights as well as civil and political rights, and issues that have been viewed from the perspective both of violations by state actors and abuses by non-state actors. It has indeed been asserted that oil, gas and mining industry operations too often go hand-inhand with allegations of human rights abuses. ${ }^{10}$ According to Oil Change International: 11

There is an alarming record of human rights abuses by governments and corporations associated with fossil fuel operations, resulting in appropriation of land, forced relocation, and even the brutal and sometimes deadly suppression of critics. In addition to strong evidence for a 'repression effect' from oil production, in which resource wealth thwarts democratisation by enabling governments to better fund internal security, dependence on oil is associated with a higher likelihood of civil war. Additionally, oil production has been found to negatively impact gender equality by reducing the number of women in the labor force, which reduces their political influence.

To prove the above, cases of human rights violations associated with oil are mentioned, including those from Nigeria and Myanmar, but the United States of America and Canada as well, which demonstrates that this problem is not restricted to developing countries. ${ }^{12}$ The Energy Justice Network on its website lists a total of 29 conflicts associated with oil from countries across the world. ${ }^{13}$ The Niger Delta in Nigeria stands out in Africa as an area where oil activities have wrecked people's lives and brought about untold suffering resulting from serious environmental degradation, unlawful evictions and the destruction of houses and food gardens, as well as deaths. ${ }^{14}$ The killing of Ogoni human rights activist Sarowiwa by the Nigerian government under Sani Abacha is fresh in the minds of many.

9 The example can be given of conditions imposed upon the government of Chad as part of the agreement to fund the construction of a pipeline from Chad to Cameroon.

10 Amnesty International, USA 'Oil, gas and mining industries' http:// www.amnestyusa.org/our-work/issues/business-and-human-rights/oil-gas-andmining-industries (accessed 24 January 2017).

11 Oil Change International 'The price of oil: Human rights violations' http:// priceofoil.org/thepriceofoil/human-rights (accessed 24 January 2017).

12 As above.

13 Energy Justice Network 'Blood for oil: Oil and gas interests vs people and the environment' http://www.energyjustice.net/bloodforoil (accessed 24 January 2017).

14 See Social and Economic Rights Action Centre (SERAC) \& Another v Nigeria (2001) AHRLR 60 (ACHPR 2001). 
A 2016 report published jointly by Publish What You Pay (PWYP) and Civicus paints a grim picture for activists working on natural resource issues and highlights the dangers they face. ${ }^{13}$ The report reveals the number of reported killings associated with advocacy for natural resources justice, numbering 185 in 2015, compared to 88 in 2010. The total number between 2010 and 2015 stands at 753. ${ }^{16}$ Means used to restrict the work of activists, according to PWYP and Civicus, include the law and extra-legal means. The legal means include regulations that suffocate civil society; tight control of public space; and the criminalisation of activists. The extra-legal means include vilifying those who speak out; unwarranted surveillance; and intimidation and violence. ${ }^{17}$

It is on the basis of the above that human rights defenders have embarked on work in this sector with the aim, according to the Eastern and Horn of Africa Human Rights Defenders Project, of seeking to influence both the regulatory frameworks governing the extractive sector as well as public discourse. This purpose in itself influences policy making, raising the alarm when actors diverge from their responsibilities or when abuses go unaddressed. ${ }^{18}$ Indeed, the work of human rights defenders is beginning to pay off, as is evident from the recent suspension of Azerbaijan from the Extractive Industries Transparency Initiative (EITI) for failing to lift restrictions on civil society freedoms. ${ }^{19}$

In Uganda, civil society organisations working in the oil and gas sector have organised themselves in coalitions such as the Civil Society Coalition for Oil (CSCO), which plays a significant role in human rights advocacy in the oil and gas sector. The umbrella organisation fulfils its objectives mainly through advocacy; capacity building; research; and engaging with oil companies and government departments and communities in areas directly affected by oil exploration. ${ }^{20}$ Action Aid has established a website on 'Oil in Uganda' which is dedicated to providing necessary and significant information to the general public on oil and gas activities in the country. ${ }^{21}$ CSOs have also been very instrumental in legislative advocacy through making submissions on various laws before they are passed into law,

15 Publish What You Pay and Civicus 'Against all odds: The perils of fighting for natural resource justice' December 2016, http://www.civicus.org/images/Against AllOdds\%20\% 20PWYPCivicus\%20reportoncivicspace(1).pdf (accessed 21 March 2017).

16 Publish What You Pay and Civicus (n 15 above) 8.

17 Publish What You Pay and Civicus 10.

18 East and Horn of Africa Human Rights Defenders Project 'Only the brave talk about oil': Human rights defenders and the resource extraction industries in Uganda and Tanzania (2012) 1.

19 Acts Activism Education Research 'Azerbaijan suspended by extractive industries governance watchdog' http://platformlondon.org/2017/03/16/azerbaijan-suspen ded-by-extractive-industries- governance-watchdog/ (accessed 20 March 2017).

20 See the website of the Civil Society Coalition on Oil and Gas http://csco.ug/\# (accessed 13 April 2018).

21 See http://www.oilinuganda.org/about (accessed 13 April 2018). 
such as the comments offered on the National Environment Bill by $\mathrm{CSCO}^{22}$

\subsection{Oil and gas: Ugandan context}

In Uganda, oil exploration began as early as the 1950s but was halted following a sharp fall in the price of oil, only to be aggressively resumed in the mid-2000s. The 2000s were an incentive for oil exploration as one witnessed a sharp and steady rise in the price of a barrel of oil. ${ }^{23}$ The first discoveries were made in 2006, and since then government has made strenuous efforts to establish the requisite legal and administrative infrastructure to enable it to produce approximately 1,4 billion barrels estimated to be recoverable out of the total estimate of 6,5 billion barrels that have been discovered to date.

In December 2013 the Uganda Human Rights Commission (UHRC) published a report on what it described as emerging human rights issues in the Albertine oil region. ${ }^{24}$ The Commission report indicates that its publication followed investigations conducted in the districts of Hoima, Bulisa, Nebbi, Nwoya and Amuru, prompted by various petitions alleging human rights violations in these districts. The Commission found issues with respect to compensation by government to those whose land had been expropriated to pave the way for the oil exploitation and processing activities, especially in Hoima District. In some respects the compensation rates used were inadequate and in some places in Nebbi the land was taken away before compensation had been finalised. ${ }^{25}$

The UHRC also took issue with regard to the extent to which people were consulted and involved in making decisions on matters that affected them, thereby asseting the right to participation. ${ }^{26}$ There were participation deficits in determining the compensation rates as well as with respect to the choice of services that some corporations provided as part of corporate social responsibility. Equally, the traditional institutions in the area, including the Kingdom of Bunyoro, had not been involved in the oil activities which, according to the UHRC, implicated a violation of the right to self-determination. The Commission examined this issue from the perspective of the right of peoples to dispose of natural resources, stating: 27

It is important that people are not denied meaningful say in government and in decisions on disposal and benefit of natural resources. The African

23 B Augé 'Oil and gas in Eastern Africa: Current developments and future prospects' (2015) French Institute of International Relations and OCP Policy Centre 8.

24 Uganda Human Rights Commission 'Oil in Uganda: Emerging human rights issues. Special focus on selected districts in the Albertine Graben' December 2013. Uganda Human Rights Commission (n 24 above) 17.

26 Uganda Human Rights Commission 18-19.

27 Uganda Human Rights Commission 20-21. 
Commission clearly underscored the obligations of the states to take precautionary steps to protect their citizens to exercise the right to freely dispose of wealth and natural resources. It was held that the nonparticipation of the Ogoni people and the absence of any benefits accruable to them in the exploitation of oil resources by the Nigerian government and the oil companies was a breach of its obligations under the ACHPR to exercise this right in the exclusive interest of the people and to eliminate all forms of foreign economic exploitation.

Similar deficits were found with respect to the related right of access to information. ${ }^{28}$ In some cases people were not given information as to how their compensation had been determined. The authorities also were not adequately responding to requests to access information as required by law.

Other human rights violations identified by the UHRC included a violation of the right to a clean and healthy environment as a result of the pollution of the environment by dust, noise and smells, among others. With respect to workers' rights there were accusations of discrimination against the locals as far as access to work was concerned, as most of the employment positions were given to persons from other parts of the country. Related to this matter was the limited monitoring of labour standards at the work sites, in some cases because of a denial of access of labour inspectors to the sites. ${ }^{29}$

The Commission found a number of issues related to the right to land, including the selling off of communal land without following proper procedures; a lack of clarity over the government ban on acquisition of land titles in the Albertine Graben; inadequate compensation that did not take into consideration land use rights; delayed restoration of the derelict land; and the alleged forced signing of compensation disclosure agreements by some residents. ${ }^{30}$

The above concerns recorded by the UHRC confirm similar concerns raised over the years by a number of civil society actors. Surveys conducted by Global Rights Alert (GRA) further indicate how the livelihoods of people affected by the developments in the area have been destroyed. In their reports, ${ }^{31}$ the organisation has documented several violations and challenges such as limited and/or biased information; a lack of opportunities for participation; and limited access to justice.

It is against this background that the impact of the 2016 NGO Act on CSOs in the oil sector should be understood. Nonetheless, the impact cannot be fully understood without an understanding of the national and international standards and rights relevant for CSOs.

28 Uganda Human Rights Commission 21.

29 Uganda Human Rights Commission 26.

30 Uganda Human Rights Commission 27-29.

31 GRA Acquisition of land for the oil refinery: Tracking progress in resettling project affected persons who opted for land for land compensation (2015). 


\section{Civic engagement and human rights standards}

The rights of civil society should be understood in the context of three fundamental freedoms, namely, expression and association and assembly. It is on the premise of these freedoms that different civic formations, including non-governmental organisations (NGOs) and community-based organisations (CBOs), operate and on which they base their existence as a matter of right. Indeed, freedom of expression has been highlighted as the cornerstone of democracy as the latter essentially is based on free debate and open discussion. ${ }^{32}$ Democracy demands that every citizen is entitled to participate in democratic processes to enable him or her intelligently to exercise the right of making free choices and generally participate in the discussion of public matters. ${ }^{33}$

Freedom of expression and association are rights recognised by the international and regional human rights framework. The International Covenant on Civil and Political Rights (ICCPR) recognises the right of everyone to hold opinions without interference. ${ }^{34}$ The right to freedom of expression entails the right to seek, receive and impart information including ideas of all kinds in any form. ${ }^{35}$ The ICCPR also recognises the right to freedom of peaceful assembly in article 21 and freedom of association in article 22 . These rights are also protected in the African Charter on Human and Peoples' Rights (African Charter). ${ }^{36}$ Suffice to note that these rights are not absolute and can be limited for purposes of security or public safety, public order, the protection of public health or morals or the protection of the rights and freedoms of others. ${ }^{37}$ However, the restrictions placed on these rights must be prescribed by law and must be necessary and justifiable in a democratic society. 38

The Ugandan Constitution is in line with the ICCPR and the African Charter in as far it protects the above rights in article 29 and prescribes allowable limitations on derogable rights. ${ }^{39}$ Notwithstanding these constitutional guarantees, civic space in Uganda is circumscribed with CSOs encountering a myriad of obstacles in the course of their operations. These obstacles cumulatively have shrunk the space within which the CSOs operate. The obstacles, among others, stem from legislation that both directly and indirectly govern the activities of CSOs. The impediments in the law include hurdles in the form of procedural setbacks that affect efforts by CSOs to foster

Manika Ghandhi v Union of India [1978] 2 SCR 621.

As above.

Art 19(1) ICCPR.

Art 19(2) ICCPR.

See arts 9 and 10 of the African Charter.

Art 22(2) African Charter.

Art 22 African Charter

Art 43(1) Constitution. 
democratic governance. The weight of overcoming these hurdles primarily is felt by pro-democracy and anti-corruption CSOs, as well as those working on crucial and sensitive issues such as oil and gas that call for accountability from government. ${ }^{40}$ This kind of working environment has orchestrated a difficult and suspicious relationship between the organisations and the state. ${ }^{41}$ There is limited cooperation between the government and organisations working in areas that demand accountability from the state. ${ }^{42}$ Indeed, the relationship of suspicion has seen CSOs accuse government of being responsible for over 13 office break-ins that some NGOs, especially around Kampala, have suffered in recent times. ${ }^{43}$

\section{Legal regime governing civil society organisations in Uganda}

Prior to the enactment of the 2016 NGO Act CSOs were governed by the Non-Governmental Organisations Registration Act, an Act that had been in force since 1989, undergoing major amendment in 2006. The 1989 Act as it stood was specifically intended to provide for the registration of NGOs. All NGOs were required to register with the National Board of Non-Governmental Organisations (NGO Board) prior to their operation. The rest of the Act was focused specifically on the establishment of the Board and providing for its functioning. The 2006 amendments were intended to provide for closer monitoring of NGOs by the state. To this end the composition of the NGO Board was reviewed to include state security representatives from the internal security organisations (ISOs) and external security organisations (ESOs). ${ }^{44}$ The presence of these security officials on the Board was perceived to subject CSOs to continuous and intrusive monitoring by the state. This situation had the potential of coercing self-censorship in calling for state accountability and of curtailing their freedom of expression. ${ }^{5}$ The 2006 amendment also introduced vague provisions that gave the NGO Board discretionary powers such as the refusal to register an organisation if its constitution was in contravention of the law. ${ }^{46}$ It has been argued, however, that the Act

40 Interview with Nicholas Opiyo, Executive Director, Chapter Four Uganda, held on 31 February 2017.

41 As above.

42 Interview with Patrick Tuwmine, Board member, Global Rights Alert, held on 30 January 2017.

43 On 15 May 2014, the offices of Hurinet were broken into; https://www.hurinet. or.ug/wp-content/uploads/2015/press\%20realeses.php (accessed 20 February 2017). On 22 May 2016, the Human Rights Awareness and Promotional Forum (HRAPF) offices were broken into; http://hrapf.org/press-release-violent-break-inat-hrapf-offices/ (accessed 20 February 2017).

$44 \operatorname{Secs} 4(2)(\mathrm{e})$ \& (d) NGO Registration Act Cap 113.

45 Human Rights Watch Uganda 'Freedom of association at risk. The proposed NGO Bill and current restrictions on NGOs in Uganda' https://www.hrw.org/legacy/ backgrounder/africa/uganda/ (accessed 4 January 2017). 
also introduced some progressive provisions, which included providing for gender representation on the Board and giving NGOs automatic legal personality on registration. 47

The 2006 amendment and its attendant regulations posed serious challenges to CSOs and were the subject of a court battle challenging their constitutionality. ${ }^{48}$ However, the constitutional petition challenging the expunged law and its regulations remained unheard in the Constitutional Court and undecided since its filing in $2009 .{ }^{49}$ In these circumstances a new law was proposed in $2015 .{ }^{50}$ Judgment was delivered in April 2016, a month after the NGO Act 2016 had been passed. ${ }^{51}$ By this time the case was moot.

The government, through the NGO Board, justified the Bill on the ground that it was intended to effect the Non-Governmental Organisation Policy of 2012, which was adopted after promulgation of the 1989 Act and its 2006 amendments, which called for harmonisation. ${ }^{52}$ However, CSOs were of the view that the Bill to some extent was inconsistent with the spirit of the policy, which was chiefly concerned with the promotion and acknowledgment of the role of NGOs. ${ }^{53}$ The Bill was perceived as being intended to stifle rather than promote civil society work. For instance, it was felt that the Bill had been designed to legislate the draconian provisions of regulations promulgated after the 2006 amendment.

Resilient civil society efforts called for the revision of several provisions in the proposed law. This included clause $33(1)(d)$ of the Bill that provided for the revocation of a permit of any organisation if in the opinion of the NGO Bureau it was in the public interest to do so. ${ }^{54}$ Following stern lobbying efforts by CSOs, a number of provisions were later removed from the proposed legislation when it

46 Sec 2(d) of the Non-Governmental Organisations Registration (Amendment) Act 2006.

47 M Nassali 'NGOs, politics and governance in Uganda: A dicey relationship' (2013) 19 East African Journal of Peace and Human Rights 417.

48 HRAPF Position paper on the Non-Governmental Organisations Act 2016 (2016) 2, http://hrapf.org/research-papers/ (accessed 31 January 2017).

49 Human Rights Network \& 7 Others v Attorney-General, Constitutional Petition 5 of 2009.

50 As above.

51 The case essentially challenged the expunged law in so far as it set burdensome encumbrances on NGOs, such as compulsory registration; the requirement under the regulations to present work plans; budgets to the NGO Board as part of the registration process; and the unfettered power of the Board to annually renew permits. The petitioners argued that these were unnecessary restrictions on the freedom of association of CSOs. However, the Court ruled in favour of the respondents and stated that all restrictions on freedom of association under the expunged NGO law were necessary in a free and democratic society.

52 Chapter Four 'Position paper and clause by clause analysis of the NGO Bill 2015', http://chapterfouruganda.com/sites/default/files/downloads/CSO-Position-Paperon-the-NGO-Bill-2015.pdf (accessed 27 March 2017).

53 As above.

54 HRAPF Commentary on the recently-passed NGO Bill 2015 and its implications on organisations working on the rights of marginalised persons (2015) 7. 
was passed by Parliament. Nevertheless, the Act as passed still poses a number of threats to the operations of CSOs, more especially to those pro-democracy organisations that seek accountability from the government and those working in sensitive areas such as the oil and gas sector.

\subsection{NGO Act 2016}

Unlike the repealed legislation the 2016 Act has a wide array of objectives, which include providing a conducive and enabling environment for the NGO sector; strengthening and promoting the capacity of NGOs and their mutual partnership with the government; making provision for the corporate status of the National Bureau of NGOs (Bureau); and providing for its capacity to register, regulate, coordinate and monitor NGO activities.

Section 7 of the Act grants wide and discretionary powers to the Bureau. These include the power to discipline an NGO by 'blacklisting' or 'exposing an affected organisation to the public' or even the revocation of the permit of an organisation. The Act does not define what is meant by 'blacklisting' or how long blacklisting as a proposed form of disciplinary action should last and its implications for the organisation affected. Furthermore, the Act and its proposed regulations do not specify at what stage each of the powers of the Bureau specified under section $7(1)(b)$ of the Act can be invoked or what should be adopted as a disciplinary form of action of last resort. Rather, these powers are open to be exercised by the Bureau at its discretion at any given time as a disciplinary measure and, based on the Bureau's discretion, it can exercise any of its powers under section 7, including the revocation of an organisation's permit at any time. Equally, the power of the Bureau to expose an affected organisation to the public has the overall potential effect of discrediting CSO efforts in seeking accountability from the state or in advocating human rights.

Unlike the expunged legislation where state security officials of ISOS and ESOs were members of the NGO Board, the new Act has moved these officials to the district and sub-county committees. Sections $20(2)(d)$ and $21(2)(d)$ of the Act respectively provide for the presence of state security officials on district non-governmental organisations monitoring committees (DNMCs) and sub-county non-governmental organisations monitoring committees (SNMCs). The SNMCs have power under section 20(3)(e) to report to DNMCs on matters of organisations in the sub-county. The DNMCs, in turn, monitor and provide information to the Bureau regarding the activities and performance of organisations in the district under article 20(4)(f). Suffice to note, most activities by NGOs working on oil and gas issues take place at the community level in the districts and sub-counties in the Albertine Graben. Therefore, the presence of state security officials on DNMCs and SNMCs creates a platform for continuous securitybased monitoring of NGO activities by the state. This brings into issue 
its potential impact, considering the perception by the public of security agencies. It creates the potential for the security apparatus to be used to coerce CSOs and even force them into self-censorship in the exercise of their freedom of peaceful assembly and expression due to fears of reprisal.

In addition, the Act appears to create a long and tedious registration process under part VIII. This requirement has the potential of making registration of new NGOs unnecessarily difficult and could stifle operations of NGOs and CBOs working in various parts of the country. During the application and issuing of a permit for an NGO, the Act requires an organisation to specify the areas under which it will carry out its activities, as well as the geographical area of coverage of the organisation. This implies that an organisation cannot operate or carry out any of its activities outside the areas prescribed in its permit. Moreover, the section ignores the nature of NGO work, of which for the most part the activities and areas of operation are flexible, affected by the project-based nature of funding. This section has the potential to limit geographically NGO operations as well as to curtail their constitutionally-established freedom to work in any part of the country. The section also creates a protracted requirement that every time an NGO commences a new project which requires the organisation to expand its areas of operation, it should go through the process of acquiring authorisation from the Bureau through the DNMC of the specific area, as is seen in section 44(b).

The Act further reinforces the state's grip on CSOs by providing for inspections of NGO premises and their archives. The Act grants powers to an inspector, after giving notice of at least three working days to an organisation, ${ }^{55}$ to inspect the premises of the organisation and to request 'any information' which appears necessary 'for purposes of giving effect to the Act'. The inspection powers under section 41 of the Act are wide and discretionary and present the effect of unwarranted searches of NGOs working on sensitive areas such as oil and gas. These powers equally have the effect of establishing an opening for unfounded disciplinary action against these organisations and which is aimed merely at crippling their activities.

The Act in section 44 creates vague and open-ended 'special obligations' on the part of NGOs that can be given any convenient interpretation by the state. Some of these obligations include the prohibition of organisations from engaging in any acts that would be prejudicial to the security and laws of Uganda under section 44(d) of the Act. The Act equally prohibits organisations from engaging in any act which is prejudicial to the 'interests of Uganda and the dignity of the people of Uganda' in section 44(f). The effect of this provision is discussed in part 5 below. 
The Act further obliges organisations to be non-partisan in section 44(g). This obligation equally poses a threat to NGO activities and has the potential to curtail meaningful collaboration between NGOs and pertinent opposition stakeholders as these collaboration efforts will be viewed as 'political' or 'partisan'.

\subsection{Public Order Management Act}

In addition to the principal NGO legislation, recently retrogressive and draconian legislation, at the very least in their implementation, have been adopted. ${ }^{56}$ The legal regime has created an environment where CSOs cannot objectively interrogate issues without fear of reprisal or prosecution. Among these is the POMA, which in itself presents impediments to the exercise of the right to freedom of peaceful assembly. A number of activities by CSOs involve what would constitute a public meeting under the POMA.

The POMA has generally been criticised for its failure to create a presumption in favour of the exercise of the right to freedom of peaceful assembly or the duty of the state to facilitate peaceful assemblies. The Act does so by creating a de facto authorisation procedure for peaceful assemblies, which is unnecessarily bureaucratic with a broad discretion for the state to refuse notification. 57 The Act further grants law enforcement authorities the mandate to use force to disperse assemblies, without proper guidance for alternative methods of managing public order disturbances. ${ }^{58}$ It equally criminalises the organisers of assemblies for the unlawful conduct of third parties. ${ }^{59}$ The Act has the effect of shrinking civic space in Uganda and stifling civil society efforts in the discussion of governance, accountability, the rule of law and human rights.

\subsection{Law and policy on petroleum}

The National Oil and Gas Policy is commendable for recognising the role that CSOs can play in advancing human rights in the oil and gas sector. It recognises that CSOs can promote and protect human rights in the sector through advocacy, mobilisation and dialogue with communities and holding different players accountable with regard to oil and gas issues. This role is in addition to amplfying the voices of

56 Keynote address on the Global Day of Citizen Action by the Centre for Constitutional Governance (CCG) titled 'The shrinking civic space in Uganda undermines human rights and governance' delivered by Joshua Joseph Niyo on 16 May 2015.

57 As above.

58 Article 19 'Legal analysis of Uganda's Public Order Management Act' http:// www.article19.orf/resources.php/resources.php/resource/37331/en/uganda:-pub lic-order-management-act (accessed 30 January 2017).

As above. 
the poor in the design, monitoring and implementation of programmes in the oil and gas sector. ${ }^{60}$ The Policy provides: ${ }^{61}$

Civil society organisations (CSOs) and cultural institutions can play a role in advocating, mobilising and holding dialogue with communities; contributing to holding the different players accountable with regard to oil and gas issues; participating in getting the voices of the poor into designing, monitoring and implementation of programmes in the oil and gas sector. CSOs may also be contracted in the delivery of various services, especially in the communities where oil and gas activities will be undertaken.

Indeed, CSOs working in the oil and gas sector have undertaken numerous activities in advocating human rights in the sector. For example, Global Rights Alert has spearheaded the inclusion of women and the youth in natural resource governance in the districts of Buliisa, Hoima, Mubende and Tororo. ${ }^{62}$ The CSCO has participated in legislative advocacy with reference to different pieces of legislation on natural resource governance. They have, for example, appeared before the Parliamentary Committee on Natural Resource Governance to make submissions on the the National Environment Bill of 2017.63 Nonetheless, despite the foresight of the policy with regard to the CSO role in the sector by the National Oil and Gas Policy, these organisations have experienced many difficulties in carrying out their activities.

Some NGOs in the past have reported experiencing incidents of being summoned after holding meetings with communities, and on some occasions their meetings have been stopped by resident district commissioners (RDCs) even when they were sanctioned by the police. ${ }^{64}$ This has occurred even in the case of meetings attended by security officials, and unsubstantiated accusations of inciting people have been made against CSOs. Other incidents included RDCs stopping meetings and demanding clearance from the Permanent Secretary Ministry of Energy even if there is no law requiring this. ${ }^{65}$ Indeed, there are no criteria presented by the Ministry, and obtaining

60 Ministry of Energy and Mineral Development, sec 7(3) of the National Oil and Gas Policy - Popular Version, April 2014, http://www.eisourcebook.org/cms/January \%202016/Uganda\%20National\%20Oil\%20and\%20Gas\%20Policy\%202014.pdf (accessed 20 March 2017).

61 Ministry of Energy and Mineral Development (n 60 above) para 3.3.

62 Website of Global Rights Alert https://globalrightsalert.org/what-we-do/genderand-extractives (accessed 13 April 2018).

63 Website of the Civil Society Coalition on Oil and Gas sco.ug/data/mreports/77/ CSCO\%20APPEARS\%20BEFORE\%20THE\%20PARLIAMENTARY\%20COMMITTEE\% 20ON\%20NATURAL\%20RESOURCES\%20TO\%20MAKE\%20SUBMISSION\%20ON \%20THE\%20NATIONAL\%20ENVIRONMENT\%20BILL,\%202017\%20.html (accessed 13 April 2018).

64 Interview with Winfred Ngabiirwe, Executive Director, Global Rights Alert, 5 March 2016 at GRA Office, Kampala, Uganda.

65 As above. 
authorisation is difficult. ${ }^{66}$ Although the situation appears to have improved, the 2016 Act appears to review the obstructive course.

\subsection{Access to Information Act 2005}

The main objective of this Act is to provide for the modalities for access to information pursuant to article 41 of the Constitution. According to the Constitution, every citizen has the right of access to information in the possession of the state or any public body. The exception is with respect to information that has the potential to prejudice the security or sovereignty of the state or to interfere with the right to privacy of another person if released. ${ }^{67}$ The National Oil and Gas Policy highlights the need to promote high standards of transparency and accountability in licensing, procurement, exploration, development and production operations as well as the management of revenues from oil and gas. ${ }^{68}$ However, the sector is tainted with so much secrecy and bureaucratic obstacles that make it difficult for CSOs to access information on oil and gas. The challenges in accessing information are associated with the fact that at government level issues related to oil and gas are highly centralised and bureaucratic, thus making it difficult for most people to gain access. ${ }^{69}$ The sector has been described as 'opaque' as far as information is concerned. ${ }^{70}$ The secrecy surrounding the sector also prompted a group of CSOs working on oil governance to petition the Parliamentary Committee on Commission Statutory Authorities and State Enterprises (COSASE). COSASE is the Parliamentary Standing Committee that investigated the controversial oil cash pay-outs to 42 state officials after the government had won a legal tax dispute against the Tullow oil company. The CSOs have argued that increased secrecy in the oil sector is likely to trigger the situation of an 'oil curse' in the country. ${ }^{71}$

Although it has been reported that the situation of CSOs working in the oil sector has gradually been improving, oil-related issues remain sensitive, with CSOs experiencing problems accessing information on these issues in the Albertine region. ${ }^{72}$

66 As above.

67 Sec 5(1) Access to Information Act 2005.

68 Guiding Principle 5.1.3 of the National Oil and Gas Policy of Uganda.

69 Interview with Francis Mugerwa, journalist reporting on oil and gas issues for the Daily Monitor, conducted in Hoima on 17 February 2017.

70 Interview with Onesmus Mugyenyi, Deputy Executive Director, Advocates Coalition for Development and Environment, conducted on 16 March 2017.

71 Oil in Uganda 'CSOs call for end of secrecy in oil deals in a petition to parliament' http://www.oilinuganda.org/features/civil-society/csos-call-for-end-of-secrecy-inoil-deals-in-a-petition-to-parliament.html (accessed 13 April 2018).

Focus Group discussions in Hoima on 17 February 2017. 


\section{NGO Act and potential impact on civil society organisations working in oil and gas}

As illustrated, fears that the NGO Act would negatively impact on CSOs in Uganda were raised from the time the Bill that birthed the Act was published on 10 April 2015. It has been reported that concerted advocacy resulted in a review of the Bill to remove some provisions considered repressive. ${ }^{73}$ CSO lobbying saw the removal of clauses that would have required all NGOs to re-register when the Act came into force. The initial Bill had also given the NGO Bureau substantial power, and in some clauses these were judicial powers. ${ }^{74}$ Nonetheless, the Bill was passed with some contentious clauses which have now become law. It has been argued that the major thrust of the Act is to establish a dense regulatory framework. Under this broad discretion and subjective rules, even the most compliant organisation could be warned, sanctioned or ultimately deregistered. ${ }^{75}$ This aim has partly been achieved through what has been described as a 'thick bureaucracy'. ${ }^{76}$ The bureaucracy has various regulatory structures, from the national level in the form of the National Bureau for NonGovernmental Organisations through to structures at district and subcounty levels.

The government has argued that the Act was created to help improve and harmonise the operations of NGOs and is not intended to target any NGOs as government acknowledges and appreciates the good work NGOs are doing. ${ }^{77}$ Unfortunately, this is not how CSOs interpret the Act. It has been argued that the Act was not drawn up in good faith and with good intentions; rather that the law was promulgated to increase the avenues and processes that could be used to 'deal' with CSOs. This is why the Act creates many opportunities for the state to attack CSOs at various levels, from national and through to local bureaucracies. ${ }^{78}$ Although it has been acknowledged that there was misconduct, among others, the presence of briefcase CSOs that were exploiting people, the Act went far beyond dealing with this problem and instead punishes legitimate CSOs. $^{79}$ As a matter of fact the CSOs view the Act as imposing a

73 A Jjuuko 'Speaking out against the Non-Governmental Organisations Act, 2016 so that we may keep our voice' in Human Rights Awareness and Promotion Forum The potential impact of the Non-Governmental Organisations Act 2016 on marginalised groups December 2016, 8.

74 As above.

75 K Busingye 'Forest from trees: Placing the Non-Governmental Organisations Act 2016 in context' in HRAPF (n 48 above) 18.

76 As above.

77 Interview with Okello Stephen, Acting Executive Director, NGO Bureau, 8 February 2017.

78 Interview with Bashir Twesigye, Executive Director, Civil Response on Environment and Development (CRED), conducted on 15 March 2017.

79 Interview with Peter Magela Peter Gwayaka, Programme Office, Chapter Four, on 20 March 2017. 
tedious registration process and creating a thick layer of bureaucracy that could negatively impacts on their operations.

\subsection{Tedious registration processes}

The thick bureaucracy is characterised by tedious procedures and requirements for registration and obtaining a permit to operate. In the first place an organisation has to be incorporated under a legal regime that provides for incorporation, which could be for companies, trustees or other form of incorporation. Only after this procedure may the organisation apply to be registered by the Bureau. ${ }^{80}$ Indeed, to be registered the Act requires the organisation to make an application accompained by a certificate of incorporation, a copy of the organisation's constitution and 'evidence of statements made in the application as the Minister may prescribe'. ${ }^{81}$

The above restrictions have been bolstered by the recentlypromulgated Non-Governmental Organisations Regulations. ${ }^{82}$ For instance, the Regulations require an application for registration, in addition to the above documents stipulated in the Act, to be accompained by a chart showing the governance structure of the organisation; a copy of valid identification documents of at least two founder members; a workplan and budget; minutes and resolutions of the founders of the organisation; a statement complying with section 45 of the $\mathrm{Act}^{83}$ and recommendations by the district $\mathrm{NGO}$ monitoring committee of the district where the organisation is headquartered, or a responsible ministry or ministries. 84

\subsection{Permission to operate and reporting obligations}

Even after fulfilling the above registration requirements an organisation has to apply for a permit from the Bureau, a process which involves paper work and comes with a number of obligations. 85 An applicant for a permit has to supply information in a number of areas, including the operations of the organisation; its areas of operation; the areas in which the organisation may carry out activities; the staffing of the organization; the geographical area of coverage; and the location of the organisation, in addition to paying the prescribed fees. ${ }^{86}$ It has been argued that it is not proper that an entity which has been incorporated, which in itself amounts to

$80 \operatorname{Sec} 29$.

81 Sec 29(2)(a).

82 Non-Governmental Organisations Act, Statutory Instrument 22 of 2017.

83 Sec 45 has various requirements pertaining to the staffing of an organisation.

84 See Regulation 4.

85 Sec 31.

86 As above. 
authorisation to operate countrywide, is required to obtain a permit and obtain approval from other local government structures. ${ }^{87}$

The bureaucratic maze continues. As illustrated above, an organisation wishing to carry out activities in any part of the country has to get approval from the District NGO Monitoring Committee from each district where it wishes to operate, as well as to enter into a memorandum of understanding with the district. ${ }^{88}$ CSOs working on oil and gas issues in the Albertine region have argued that this requirement escalates the challenges they already face as it may be manipulated by some districts to make operations difficult for CSOs. Indeed, a close scrutiny of the process shows that the permit obtained from the Bureau is useless since it can be defeated by a district refusing to enter into a memorandum of understanding with a CSO. ${ }^{89}$

To illustrate the potential effect of the section 44(a) bureaucracy, Busingye argues as follows: ${ }^{90}$

For instance, to take but one example, in terms of section 44 of the Act no organisation may carry out activities in any part of the country unless it has received the approval of the District NGO Monitoring Committee and Local Government of that area and has signed a memorandum of understanding with the Local Government to that effect. The essence of this provision is that, in addition to the requirement to register with the NGO Bureau, an NGO wishing to operate throughout Uganda would be required to seek and obtain the permission of 112 District NGO Monitoring Committees and as many Local Governments. The difficulty of such an undertaking, even for the better-resourced NGOs, cannot be overexaggerated.

It has been argued that the requirement for memoranda can be abused by local leaders who may want to avoid public scrutiny and accountability by locking out CSOs they consider aggressive and those working against their interests. For instance, a leader who gets a negative review from a CSOs may work to ensure that the memorandum of understanding is not renewed. ${ }^{91}$ Indeed, some CSOs working on oil and gas also work on other accountability and governance issues. The example here includes those CSOs which, for instance, have a local government performance scorecard programme under which the performance of district councils and local leaders are assessed. It is feared that local leaders who are not satisfied with the scorecard project may decide not to sign a memorandum of understanding. ${ }^{92}$

87 Interview with Gad Benda, Chairperson, PWYP-Uganda and Executive Director, World Voices, on 15 March 2017.

88 Sec 44(a).

89 Interview with Peter Magela Peter Gwayaka (n 79 above).

90 As above.

91 As above.

92 Interview with Onesmus Mugenyi (n 70 above). 
Furthermore, it is not clear what misconduct the requirement to sign memoranda was designed to deal with. ${ }^{93}$ In addition, it has been reported that some district officials are abusing the law by reminding CSOs that their memoranda with the districts are about to expire and have demanded bribes to facilitate renewal. ${ }^{94}$ This activity is suspected to arise from the fact that the requirement for memoranda is now legislated. Previously some CSOs had entered into memoranda with some districts on a purely voluntary basis as a way of promoting collaboration. With the new law in place, the districts have been given power over CSOs, which explains why some officials are now demanding bribes. ${ }^{95}$ It is feared that the Act and the influence of security personnel and members of the DNMCs and SNMCs may result in previously co-operative districts shunning the work of CSOs working on oil and gas. ${ }^{96}$

A further level of bureaucratic control lies with section 39 reporting requirements. The provision requires organisations to declare and submit to the district technical planning committees, the DNMCs and the SNMCs details about the areas in which they operate, estimates and sources of their funds. ${ }^{97}$ In addition, the provision in an openended manner requires the organisation 'to submit to the Bureau, DNMC and SNMC in the area of operation, any other information that may be required. ${ }^{\prime 98}$ This demand adds to the layers of bureaucracy and administrative requirements that are likely negatively to impact on CSOs, and a failure to comply may be used to deny an organisation a permit or to revoke the same. ${ }^{99}$ To understand the magnitude of this burden, the Albertine region, for instance, has up to 22 districts, meaning that an organisation working in this area would have to prepare 42 returns. This duty is not only tedious but resourceconsuming, and eats into the administrative time a CSO allocates for its activities. 100

It should be noted that some organisations working on oil and gas, in addition to grassroots work, also operate at the national level. The levels of administrative bureaucracy that runs through the local government structures creates the potential of stifling the work of organisations that are more difficult to stifle at the national level. The bureaucracy could be used to make it impossible for them to operate at local level, which would deny them access to communities. ${ }^{101}$

\footnotetext{
93 Interview with Gad Benda (n 87 above).

94 Interview with Bashir Twesigye (n 78 above).

95 As above.

96 Interview with Richard Orebi, Hoima Field Officer for Global Rights Alert, on 16 March 2017.

97 Sec 39(2)(b).

98 Sec 39(2)(c) (our emphasis).

99 Interview with Onesmus Mugyenyi (n 70 above).

100 Interview with Peter Magela Peter Gwayaka (n 79 above).

101 As above.
} 


\subsection{Public interest and security}

Among the provisions described as disquieting are sections 44(d) and (f). These provisions are set out verbatim:

44 Special obligations

An organisation shall -

(d) not engage in any act which is prejudicial to the security and laws of Uganda;

(f) not engage in any act which is prejudicial to the interests of Uganda and the dignity of the people of Uganda ...

CSOs have faulted the above provisions on the ground that they are vague and could be abused in ways which negatively impact on CSO work. It has been argued that the provisions use words that are broad and undefined and could be used to limit the enjoyment of the right to freedom of association. ${ }^{102}$ Indeed, the use of such vague provisions is not uncommon. The phrase 'prejudicial to security', for instance, could be used to clamp down on freedom of expression. It is also demonstrated that the phrase 'laws of Uganda' could be abused.

jjuuko has argued that the terms 'prejudicial' and 'interests of Ugandans' can be interpreted very broadly and are malleable according to the purpose and motive of the interpreter. ${ }^{103}$ To quote Kabumba, '[t]hese apparently benign words in essence incorporate into the NGO regulatory regime the whole gamut of laws increasingly used to restrict not only civic space but human rights generally in Uganda'. ${ }^{104}$ It has been argued that there is a risk that security personnel could abuse this provision for their selfish benefit since some of them are involved in aggressions such as land-grabbing in the oil-rich region. ${ }^{105}$ It has been argued further that the section was deliberately crafted in a vague manner so that it at any time can be 'bent' and used against CSOs if deemed necessary by the state. ${ }^{106}$ Although there is no evidence of the Act being used for these purposes, it has been argued that this is because at the moment there is no serious activity stirring controversy. It is feared that when serious activities such as the pipeline and refinery works start, the Act will be dusted off and used against CSOs setting out to scrutinise the impact of these activities. ${ }^{107}$ As has been the case, this action is likely to target those organisations seeking to interface with communities at the grassroots level. It is reported that some organisations fearing the

102 Human Rights Awareness and Promotion Forum The NGO Bill 2015 and its practical and human rights implications on organisations working on the rights of marginalised persons (May 2015).

103 Jjuuko (n 73 above) 8.

104 Busingye (n 75 above) 19.

105 Interview with Gad Benda (n 89 above).

106 Interview with Bashir Twesigye (n 80 above).

107 Interview with Dickens Kamugisha, CEO, African Institute for Energy Governance (AFIEGO), on 20 March 2017. 
effects of the law have decided to stop activities in the sector of oil and gas. ${ }^{108}$

Organisations working on oil and gas issues in the Albertine area have testified that for a long time working on oil and related issues has been considered sensitive and taboo. This was the case even with organisations engaged in activities such as empowering people to demand adequate and prompt compensation. ${ }^{109}$ At a certain point, government threatened to revoke the permits of some organisations. ${ }^{110}$ Indeed, the perception of many government agencies, including security personnel, is that CSO work is intended to oppose government and interferes with government programmes, in addition to promoting donor interests. ${ }^{111}$

What makes the oil sector unique arises from the fact that this industry is globally characterised by serious rights violations, including land grabbing and environmental degradation. In addition, the sector is controlled by giant actors such as multi-national corporations and powerful state agencies. Also involved are individuals who appear to have a vested interest in the sector, which the state has positioned as the country's 'saviour'. ${ }^{112}$ An example is the recent fracas dubbed the 'golden handshake', where government officials shared millions in oil money for 'winning' an oil tax dispute. Evidence emerging shows that laws on rewarding civil servants were not followed. Another good illustration of this is the outburst by the President of Uganda, Yoweri Kaguta Museveni, in 2012, when he accused some organisations working on oil and gas as being purveyors of foreign interests. This followed advocacy work by these organisations around draft laws in this sector that were intended to ensure that the laws promote transparency. Indeed, following some engagements with members of parliament, the legislature appeared to see the need for this transparency. This development angered the President, who indicated that he had written to the Inspector-General of Government to investigate some CSOs that had led the advocacy. ${ }^{113}$ This attitude flies in the face of the National Oil and Gas Policy for Uganda which recognises the role of civil society in the oil and gas sector, as discussed earlier. ${ }^{114}$

It has been established that with or without the 2016 Act, CSOs working in the Albertine region have been facing challenges accessing

108 As above.

109 Focus Group discussions in Hoima on 17 February 2017.

110 Interview with Benon Tusingwire, Executive Director, Navigators of Development Association (NAVODA), on 15 March 2017.

111 Confirmed eg in an interview with retired Assistant Superintendent of Police, Stephen Kamanyiro, until December 2016 Community Liaison Officer, Oil and Gas police, conducted in Hoima on 17 February 2017.

112 Interview with Winfred Ngabiirwe (n 64 above).

113 See National Association for Professional Environmentalists (NAPE) 'MPs were bribed to fail Oil Bill says President Museveni'.

114 See sec 4.3 of this article. 
communities mainly as a result of the application of the POMA. As illustrated above, although the POMA does not give the police powers to authorise public meetings and only requires notice, these provisions have been misinterpreted by the police to mean that every person organising a public meeting must seek the permission of the police to do so.

Based on experience with the POMA, there is a real threat that the NGO Act could also be misinterpreted by authorities in the chain of bureaucracy which may result in abuse. CSOs in the Albertine region are concerned that if they engage in activities the authorities do not approve of, it may compromise their chances of having their operational permits renewed. ${ }^{115}$ For instance, it is feared that although the Act does not appear to give RDCs a role in the bureaucracy for the supervision of CSOs, there is the fear that RDCs my still interfere in the operations of legitimate structures. This is based on the previous conduct of some RDCs and their 'bullish' style of work. 116

Some government officials have acknowledged that weaknesses at the local level may result in some officials abusing their positions to intimidate CSOs. According to this line of argument, this is a matter requiring capacity building in the local structures which should be continouous and open to all stakeholders to enable every person to understand. ${ }^{117}$ Indeed, there is a fear that even when the Act is properly interpreted and applied, the POMA still can be misapplied, in addition to the possibility of other laws being promulgated and existing laws in areas such as terrorism and money laundering being used to clamp down on CSO work. ${ }^{118}$

\subsection{Other issues of concern}

Part IX of the Act, which deals with 'self-regulation', can also cause problems for CSOs working on oil and gas. Section 38 provides that a self-regulatory body shall inform the Bureau of its existence and mode of operations. Section 36(a) defines a 'self-regulatory body' as referring to a body set up by registered organisations that have come together and agreed that the body exercises some degree of regulatory authority over them upon consenting, or resolving that they would abide by a set code of conduct, rules and procedures. It is not very clear what the purpose of this provision is and the misdemeanour with which it deals. What is the purpose of registering the body? The danger with this provision is that it could be used to stifle the coalitions and networks which organisations working on oil and gas have formed, such as CSCO and PWYP. ${ }^{119}$ The effect of this is

115 Focus Group discussions in Hoima on 17 February 2017.

116 Interview with Winfred Ngabiirwe (n 64 above).

117 Interview with Stephen Okello, 8 February 2017.

118 Interview with Winfred Ngabiirwe (n 64 above).

119 Interview with Peter Magela Peter Gwayaka (n 79 above). 
that it may discourage organisations from forming coalitions and networks.

Section 45(c) deals with the issue of employment of non-citizens, who are not to be employed before proceeding to Uganda for the purpose of employment by an organisation that has submitted to the diplomatic mission of Uganda in their country certain credentials, including academic papers and recommendations as well a certificate of good conduct. This provision in the first place is discriminatory in that it imposes such conditions only on non-citizens seeking to work with CSOs. Second, the provision could be used to keep certain noncitizens from working with organisations in Uganda. This is likely to affect CSOs working on oil and gas to the extent that, being a new sector, CSOs in Uganda are yet adequately to build their expertise and now and again rely on foreign experts. ${ }^{120}$ Third, the provision could be used to stifle the activities of an organisation by refusing entry to foreign experts. ${ }^{121}$

\section{Conclusion}

The relationship between the government of Uganda and CSOs, mainly NGOs, has been described as 'dicey'. ${ }^{122}$ This is because, although government appears to appreciate the role of NGOs in the socio-economic development of the country, it has taken steps to closely monitor NGOs, to some extent in ways that interfere with the work of the organisations. Among others, control has been exerted using laws that govern the registration of NGOs, in addition to laws on public order management and security. It is in light of this issue that CSOs in the country received the 2016 NGO Act, a law which was promulgated amidst controversy. The Act imposes tedious processes of registration, defined by a number of pre-requisite documents. Yet, the registration is dual in nature, characterised by incorporation and subsequent registration with the NGO Bureau. The Act creates a thick layer of bureaucracy, which includes obtaining operational permits and entering into memoranda of understanding with districts.

It is feared that among those affected most by the 2016 Act are CSOs working on oil and gas issues. This fear is because of the sensitivity of this sector, which previously has seen government closely monitoring their activities and imposing stringent requirements in accessing the community, especially in the Albertine region. It is on this basis that the CSOs in the sector have expressed their fears with regard to the likely impact of the Act, which they suspect could be used to clamp down on their activities and interfere with their work.

120 As above.

121 As above.

122 Nassali (n 47 above). 
This fear is the result of the possibility of misusing bureaucratic procedures to obtain a permit and permission to work in districts. The provisions prohibiting activities that are prejudicial to security and peace can be used with the same effect. 